\title{
DISORDER OF THE TEXT GRAMMAR THEORY'S STANDARDS IN ARABIC: COHERENCE \& COHESION TERMS
}

\author{
Ayad N. Abdullah ${ }^{1^{*}}$, Zena M. Najeeb ${ }^{2}$, Milood Mustafa Ashur ${ }^{3}$, Elhadi Moh M Ohida ${ }^{4}$ \\ ${ }^{1}$ Dr, Faculty of Major Language Studies University Science Islamic Malaysia (USIM), \\ ayad@usim.edu.my \\ ${ }^{2}$ Dr, English Studies, Faculty of Major Language Studies, University Science Islamic Malaysia \\ (USIM), zenaukm@yahoo.com \\ ${ }^{3}$ Ph.D. Candidate; Arabic Studies, Faculty of Major Language Studies, University Science Islamic \\ Malaysia (USIM), miloodashur@gmail.com \\ ${ }^{4}$ Ph.D. Candidate; English Studies, Faculty of Major Language Studies, University Science Islamic \\ Malaysia (USIM), hadiohida@gmail.com \\ ${ }^{*}$ Corresponding author
}

\begin{abstract}
Over the last two decades, the study of the Arabic language and literature has gained a lot of impetus, with Arab researchers benefitting from Western linguistics. Perhaps the most important of these studies is Text Grammar Theory that saw the development of an integrated approach to the study and analysis of text, and also goes beyond the limitations of the sentence grammar. Several studies have been carried out on various texts that include poetry, literary prose of the novel, and the Holly Qur'an. With increased attention focusing on the theory standards and applications, a disorder of Arabization of the theory terms has been expanded and translations of its standards varied. This has resulted in some very obvious concepts confusion. This study aims to discuss and determine multiple Arabic translations of the theory's most important text standards, namely Coherence \& Cohesion that result in disagreements within recent Arabic linguistic studies. This disagreement is unacceptable, especially when it comes to the Holly Qur'an. To review the translations of the two standards, the researchers have adopted a descriptive analytical method as well as a deductive approach. The importance of this study is limited to standardizing the Arabic linguistic terms and framing its concepts. A survey on the most recognized Arabic linguistic studies shows that Cohesion is denoted by nine terms, while Coherence is denoted by 10 . The study also suggests that the terms (Altamasok and Al-ensijam) are the best translations because they spread widely and have clear indications. It can also be said that the reason for the disorder is that some researchers avoid rooting the mentioned terms. This study stresses on creating a function to standardize Arabic terminology and linguistic framing. This has emphasized the popularity of USIM's combination of Naqli and Aqli sciences' framework.
\end{abstract}

Keywords: Standards, Cohesion, Coherence, Text Grammar Theory, Arabic lingual term 


\section{INTRODUCTION}

The last two decades have seen Text linguistics stimulating the study of the Arabic language and literature, with Arab researchers gaining a lot from Western linguistics. Text Grammar Theory, that developed an integrated approach to the text study and analysis, and goes beyond the limitations of the sentence grammar, is perhaps one of the most important results. In 1998, Dr. Tammam Hassan translated a book which he identified as Robert De Beaugrande's Discourse and Process: Toward a Multidisciplinary Science of Texts, 1980. In this book, De Beaugrande calls for the creation of a science of texts, as well as finding standards of textuality. In 1981, De Beaugrande published another book titled: Introduction to Text Linguistics in partnership with the scholar Wolfgang Dressler, in which they presented bases of Text Grammar theory according to a descriptive method that seeks to understand the phenomenon of language, and to find out laws that govern a text. They set out 'Seven Standards of Textuality', namely: cohesion, coherence, intentionality, acceptability, informativity, situationality, intertextuality.

More than a decade after the publication of Introduction to Text Linguistics, the researchers - Ilham Abu Ghazaleh and Ali Khalil Hamad, 1992, presented a translation of enhanced chapters with applications of the seven standards on a verse from the Holly Qur'an. "They added to the Arab library an important concept of Text Linguistics, which is the adopted standards in the formation of any text to work in practice" (Shehata, Asim, 2012, p. 248).

These standards have paved the way to a holistic analysis of a text with reassuring results that can be used when reading, writing and criticizing a text, as well as in language teaching and translation studies. It also has become an important and effective tool in analyzing critical and linguistic discourse of literature. Several Arabic studies have been carried out on the standards of Text linguistics, which have also been applied on various literary texts that include poetry and literary prose.

\section{RESEARCH PROBLEM}

Confusing multiple translations of the standards of Text Linguistics can be noticed in Arabic studies and research books that have based their studies on De Beaugrande \& Dressler 1981, or even on those before the harbingers and Western researches in textuality, such as those provided by Van Dyke in his book: Some Aspects of Text Grammar, or Halliday \& Hassan (1976) in their book: Cohesion in English. Then the writers began to find Arabic labels and terms for these Western terms, away from the required rooting.

The research is limited to reviewing and discussing the views of Arab researchers who use Arab terms to denote the standard (Coherence \& Cohesion). As the two most used modern linguistic terms, as seen by researchers, they lend themselves to inaccurate and at times inappropriate use by some researchers, which might create some conceptual confusion among readers.

\section{RESEARCH OBJECTIVES}

The research aims to discuss the multiplicity of Arabic translations for the theory standards of Coherence \& Cohesion as the most important text standards. Implicitly, the use of these linguistic terms has led to some disorder in the more widespread Arabic linguistic studies.

\section{LITERATURE REVIEWS}

This research aims to uncover the problem of term multiplicity and disorder when used in modern linguistic studies. The study is based on the researchers' findings as they monitor text linguistics studies and discourse analysis. The researchers review some Arab studies that called for the need to unify the Arabic lingual term, notably:

Saad Maslouh, (1991), Grammar of Poetic Text: Study of a Poem from Jahiliya Era. This study is one of the first Arab studies that recommended the need to standardize the terms according to the culture roots, where he prefers using (Al-sabek السبك \& Al-hubek الحبك ) as the most appropriate terms to refer to Coherence \& Cohesion.

In Jam'an Abdul Karim's The Concept of Cohesion and its Importance in Textual Studies (2007), the introduction refers to the problem of terms diversity used by Arab researchers to denote the concept of Cohesion, recommending the use of the term التماسك (Al-tamasok) to refer to the concept.

In his study Consistency and Harmony in the Holy Quran (2008), Muftah bin Arous points out that, "The issue of overlap between the concepts of (Al-etisaq الاتساق) الانسجام) Rland Al-ensijamains constant in Arab Studies, and the first is usually expressed by the second." 
The study of Ashraf Abdel-Badia, (2008), The Grammatical Text Lesson in Books of the Holy Qur'an Miracles, refers to the multiplicity of terms that have been developed for Cohesion \& Coherence.

The previous studies have merely referred to the multiplicity of terms developed for Cohesion \& Coherence without indicating the reason for this diversity. They also limited to the use of particular terms without any explanation of the reason for its use, with the exception of Maslouh 1991, who calls for the need to unify the lingual term, and indicates the reason for the use of (Al-sabek \& Al-hubek) depending on the inherited rhetorical critical texts. But Jamaan, (2007) uses the term (Al-tamasoksturt) to denote the Cohesion for its prevalence more than any other terms in modern Arabic linguistic studies.

\section{TRANSLATION OF THE TERMS COHERENCE \& COHESION INTO ARABIC}

Theory of Text Grammar has adopted the term Cohesion to denote the cohesion of the parts of the text by means of verbal communication. This is agreed upon by most Arab researchers interested in the field of text linguistics and discourse analysis (Khatabi, 1991). But their agreement on the concept is accompanied by disorder in the development of the appropriate equivalent term. Several terms were spotted that Arab researchers used for the standard (Cohesion) developed by Robert De Beaugrande \& Wolfgang Dressler, (1981), among the seven standards of the Text Grammar theory. Following are the terms used by researchers and scholars of Arab linguistics.

Perhaps Saad Maslouh's "Grammar of a Poetic Text, a Study of a Poem from Jahiliya Era" that was published in Fusoul Journal 1991 is one of the first Arab critical studies that addressed the translation of the terms Coherence \& Cohesion, and applied them on a text of Arab poetry and called for rooting the two terms based to cultural Heritage. In his introduction, Maslouh says: "This study is the first attempt to test one side of the assumptions and procedures that make up the features of Text Grammar idea in a text of Arab Poetry" (Maslouh, 1991, p. 153).

It seems that Maslouh was aware of the importance of putting basis for the terms used as equivalents of the two Westerners' terms. He says that he translates the two terms basing on an objective and logical reasons imposed by the Arab culture and its heritaged literature. Relying on the critical inheritance and rhetorical heritage, Saad Maslouh uses the term (Al-sabek) to denote the Cohesion and (Al-hubek) to denote Coherence. He says they have "the closest meaning to the intended concept, and they are more common in the literature of the old criticism" (Maslouh, 1991, p. 166). It is the most appropriate translation of any based on the roots of heritage.

At the same time, he indicates the efforts of some translation researchers in translating the terms, saying: "Many attempts have been carried out to translate the terms Cohesion and Coherence, the most known are:

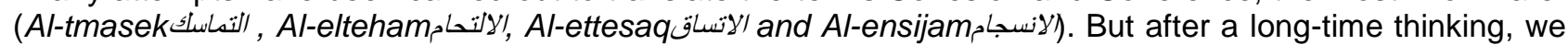

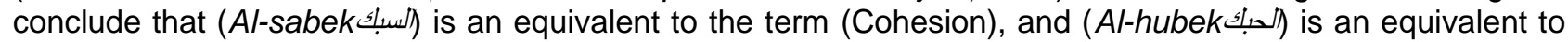
(Coherence). I daresay they are two Arabic equivalents of disclosure, readability and consistency, as they have the closest intended meaning, and more common in the literature of the old criticism." (Maslouh, 1991, p. 166)

After Saad Maslouh's attempts at rooting for the two terms, it was hoped that researchers would wrap around the efforts to unify the Arab linguistic term, but that did not happen. The survey monitors what might be called terminological disorder in the books of Arabic linguistics, in scientific thesis and in research papers in the field of text linguistics and discourse analysis.

In the same year of publishing Saad Maslouh's critical experience in1991, Mohammed Khatabi issued his book, Text Linguistics: An Entrance to the Harmony of discourse; where he says in the introduction: "It is usually meant by consistent the so strong cohesion between the parts that form any text/discourse, and cares about the linguistic means formalism" (Mohammed Khatabi, 1991, p. 5), that is, he makes (Al-

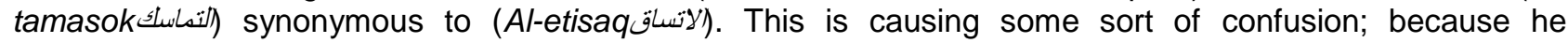
interprets the term (Al-etisaq) by the term (Al-tmasek), which is used by some researchers to denote the Coherence. Then he mentions a translation of the title of (Halliday \& Hassan's Cohesion in English) in the introduction of the first unit of his book in this way: "Al-etisaq in English Language" (Khatabi Mohammed, 1991, p. 5). Thus he translates the standard (Cohesion) to (Al-etisaq). Then he points to the same standard by (Al-trabuth/لترابط (Al-ensijam) and (Al-beniat Alkubra) (major structures) (Alkhatabi, 1991, p.27). Then he makes the term (Al-trabut) a title of a paragraph of which he speaks about the opinion of "Van Dyke" on (The concept of interdependence of issues expressed by a sentence or a consecutive text) (Khatabi, 1991, p. 34). This is the same concept of (Al-etesaq).

It seems that Khatabi opted not to use the term (Al-etisaq) when he talked about "Van Dyke"; because the latter did not use the term (Cohesion) in his book Text and Context from which Khatabi draws the views of 
Van Dyke. Van Dyke (1977, p. 126) uses the term (Connection) which is translated by Khatabi to (Al-trabut), presenting both terms (Connection) and (Cohesion) as the same term. Perhaps this explains why Salah Fadl - later - uses the term (Al-trabut) preferring the Western term (Connection) to (Cohesion). This shows that one of the reasons for the multiplicity of Arabic terms for the same concept can be attributed to the different western sources that are adopted by Arab researchers.

The multiplicity of terms that reflect the one concept cause confusion and uncertainty among readers and researchers, particularly graduate students, who are authorized by Khatbi, in the introduction to his book, to use the term (Al-etisaq) to refer to the (Cohesion) and the term (Al-ensijam) to denote the (Coherence). Then

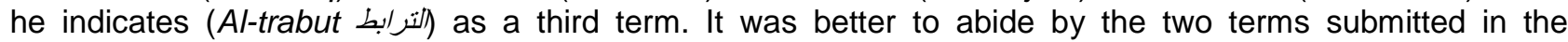
introduction to his book.

In his study Eloquence of Discourse and Text Science, which is devoted to theorizing linguistics and discourse analysis, Salah al-Fadl, (1992) does not mention the term (Cohesion), but mentions the term (Coherence) once when he spoke of textual analysis, saying: "Textual analysis therefore starts from the already achieved (Albuinah Alkubrah, major structures) which is characterized by the highest degree of (Alensijam, harmony) and (Al-tamasok, coherence)" (Salah al-Fadl, 1992, p. 236). Here are several questions about the terms display in this manner:

\section{a. Is (Al-ensijam, harmony) synonymous to (Al-tamasok) consistency?}

b. Does he mean (Coherence) by the word (Al-ensijam, harmony)?

c. Why did the author not mention (Cohesion) though he has stated (Coherence) in its English form?

When looking for answers to these questions, it is clear to us that Salah Fadl has put the term (Al-ensijam, harmony) as an equivalent to (Coherence). But for the term (Al-tamasok) we do not precisely know what he means by it here because he has used it several times and each time he was responding to a different concept. For example, he says: "The concept of (Al-tamasok) belongs to the field of understanding and interpretation" (Fadl, 1992, p. 241). He means (Coherence). He says: "(Al-ttamasok) as a prerequisite for the text has a semantic nature" (Fadl, 1992, p. 241). He means (Coherence). After that he describes (Altamasok) as "characterized by a linear feature". He means (Cohesion). Then he conveys the opinion of Van Dyke, saying "Van Dyke explains interdependence between text sequences operations, functional coherence (Al-tamasok) between the large units and the role of reading and interpretation in their identification on the basis of semantic and logical foundations" (Fadl, 1992, p. 241). The interdependence between text sequences means Cohesion. While by functional semantic (Al-tmasek), he means (Coherence). Then he confirms this distinction between (Al-trabut) "interdependence" and (Al-tamasok) in saying: "Scholars distinguish between the types of topical conditional text interdependence of the text and functional cohesion (Al-tamasok)" (Fadl, 1992, p. 243).

The new question is: What does Salah Fadl mean by "Al-trabut"? It seems that Salah Fadl has translated the term used by Van Dyke to denote the concept Cohesion; because Van Dyke used the term Connection. Salah Fadl says: "If the term (Sequences) has been used to refer to the group of sentences which is characterized with each other to achieve the (Connection) (Al-trabut), it is usual that these sequences configure texts characterized by (Al-tmasek)" (Fadl, 1992, p. 236); it highlights here the term (Connection) (Al-trabut) by Salah Fadl as an equivalent to the term (Cohesion) because it demonstrates the same concept. Confusion remains with the Arabic term (Al-tmasek) which is used to denote both concepts (Cohesion and Coherence).

Salah Fadl acknowledges the difficulty in defining the concept of (Al-tmasek), saying: "For some scholars, such as Hjelmslev, we find that (Al-tamasok) means rigidity, unity and continuity" (Fadl, 1992, p. 236). This means that Salah Fadl expresses the concept (Cohesion) by (Al-tamasok). But when he has expressed the concept of (Al-tmasek) according to scholars, he says: "They pay paramount attention to (Al-ttmasek), ... and they see that it has semantic characteristics of discourse where the text is composed of sentences and each sentence depends on what can be understood from the other sentences" (Fadl, 1992, p. 244). This means that the (Al-tmasek) here is intended to (Coherence). He confirms that, saying: "Scholars explain factors of which (Al-trabut) relies upon, regarding the surface level of the text, presented in indicators of language such as: references including pronouns, articles, conjunctions and punctuations... etc. (Fadl, 1992, p. 244). Fadl intends to point to the surface level of a text and the relations between text items in the visible text which is unique to the standard (Cohesion); therefore he has used the term (Al-tarabet) "interdependence" of which he previously expressed (Connection) as an equivalent to (Cohesion).

Based on what has been motioned above, Salah Fadl has used the terms: (Al-tarabet, Al-ensijam, Altamasok, Al-etisaq, and Al-tanaghum) in one book established for a text science and discourse analysis 
(Fadl, 1992, p. 13, 16, 236, 241, 243244 and 249). We do not know exactly which one denotes the standard Cohesion and which one denotes Coherence!

Sayid Buheiry, (1997) has developed the term (Al-rabet Al-nahawy, grammar linking) to refer to the standard Cohesion when he talked about the seven standards of textuality set by De Beaugrande and Dressler. He says, "They made the grammar link first standard, which is concerned with how to connect the surface text components, i.e. words. And semantic connection is the second standard, which means the task of which textuality components composed" (Buheiry, 1997, p. 145).

He then provides a precise definition to the concept of each standard, where he says: "The first is Cohesion, a link between linguistic signs. The second is Coherence, a link between perceptions of textuality" (Buheiry, 1997, p. 145).

In 2009, when Sayid Buheiry published the translation of a book by linguist scholar Christine Adamczyk titled: Text Linguistics Constituent Display, Buheiry referred to Cohesion by (Al-rabet Al-nahawy, grammar linking) adopted in his first book, and added the term (Al-sabek) which is reported between parenthesis, this way: "Al-rabet Al-nahawy, grammar linkage" (Al-sabek) (Buheiry, 2009, p. 112). He also cited the term (Alhubek) between parentheses with the term (Al-tamasok) in this way: "Attamasok Al-daladi (Al-hubek)" (Buheiry, 1997, p. 112) to denote the Coherence. If he only had indicated the two terms (Al-sabek and Alhubek), this work would have been recorded within the efforts for unification of the term relying on traditional roots; and he would have shared in the terms rooting process initiated by Maslouh (1991).

In his translation of De Beugrand's Text, discourse, and Process (1980); in which standards are stated, Tammam Hassan (1998) has adapted the terms (Al-sabek) proposed by Maslouh, but not (Al-hubek). He says: "(Al-sabek) (Cohesion) happens as a result of processes where the surface text elements appear in the form of events of which the former leads to the next, so as to achieve the interdependence that can be restored. This interdependence includes grammatical forms, compounds, compositions, sentences, and others such as: repetition of words, common references, deletion and conjunctions" (Hassan, 1998, p. 103).

It is clear here that Tammam Hassan adopts the translation of Saad Maslouh for the term (Cohesion) (Alsabek). But the confusion begins with the end of the same paragraph when he says: "The means of $(A /-$ tadam التضام) include ..." (Hassan, 1998, p.103). He indicates another term for the Western term (Cohesion). It is the term (Al-tadam) convergence. Tammam Hassan uses two terms to one concept. He points to (Alsabek and Al-tadam) as synonymous in denoting the Western term Cohesion. "The term (Al-hubek) developed by Saad Maslouh as an equivalent to the Coherence is referred to by Tammam Hassan as (Altadam)" (Hassan, 1998, p. 103).

Later, the author added another term for the same concept, when Tammam Hassan (2007) published his book (Linguistic Diligence) that contains translation of the standards of textuality, including a new translation for the (Coherence) which is the term (Al-taliq, 'التعليق) (Tamam, 2007 , p. 370). He does not comply with Maslouh's terms (Al-sabek and Al-hubek) nor with his own translation of De Beaugrande's Text, Discourse, and Process (1998) to Arabic, where he mentioned (Al-sabek and Al-hubek).

The problem of the proper equivalent for the term Cohesion increases with more studies and the gap between researchers' translations grows.

Ahmed Afifi (2001) marks three synonymous terms combining them with a conjunction tool. He says: "Alsabek or Al-rabet or Al-tadam (Cohesion) is a standard concerns with the surface level of the text ...." (Afifi, 2001, p. 90). When he talks about the second Standard, Afifi indicates four terms to refer to one concept, saying: "Al-hubek or Al-tmasek or Al-ensijam or Al-attisaq (Coherence)". This standard is connected to monitoring means to semantic continuity in textuality" (Afifi, 2001, p. 90).

\section{THE NEED TO UNIFY THE TERMS}

There were many translations for the standards (Coherence \& Cohesion). It has become difficult to differentiate between the two standards by most Arab researchers. For example, Afifi (2005) uses several synonymous terms to denote one concept. He also used the same term (Al-tamasok) to express different standards, namely (Cohesion and Coherence) (Afifi, 2005, p. 9, 14, 22, 29, 40, 69).

Saad Maslouh, (1991) and Jamaan Karim, (2007) have pointed out that this terminological disorder arose as a result of a large number of terms mentioned by Arab scholars. By tracking some studies of text linguistics and discourse analysis, the most popular terms used by Arab researchers to denote the (Cohesion) are nine terms: (Al-sabek, Aletisaq, Al-tamasok, Al-tadam, Al-rabet, Al-trabut, Al-trabut Arrasfi, Al-rabet Alnahawy, and Al-eltyam). While eight terms are used to denote the standard (Coherence): (Al-hubek, Al-tamasok Aldaladi, Al-ensijam, Al-etisaq, Al-taqaren, Al-tanaseq, Al-taliq and Al-tarabet). Thus, there is a need to 
standardize the term to avoid confusion in the use of the most common terms of the text, (Cohesion) and (Coherence). The following table shows more details:

\begin{tabular}{|c|c|c|c|c|}
\hline $\mathbf{S}$ & Researcher Name & Year & Cohesion & Coherence \\
\hline 1 & Salah Fadhl & 1990 & Al-trabut & $\begin{array}{l}\text { Al-tamasok Aldaladi } \\
\text { Al-ensijam }\end{array}$ \\
\hline 2 & Saad Maslouh & 1991 & Al-sabek & Al-hubek \\
\hline 3 & Mohammed Khitabi & 1991 & Al-etisaq, Al-tamasok & Al-etisaq, Al-ensijam, \\
\hline 4 & Ilham Ghazala and Khalil Ibrahim & 1992 & Al-tadam & Al-taqaren \\
\hline 5 & Said Buheiry & $\begin{array}{l}1997 \\
2009\end{array}$ & $\begin{array}{l}\text { Al-rabet, Al-sabek } \\
\text { Al-rabet Alnahawy }\end{array}$ & $\begin{array}{l}\text { Al-tamasok, Al-hubek } \\
\text { Al-tamasok Adaladi }\end{array}$ \\
\hline 6 & Tammam Hassan & $\begin{array}{l}1998 \\
2007\end{array}$ & $\begin{array}{l}\text { Al-sabek } \\
\text { Al-tadam }\end{array}$ & $\begin{array}{l}\text { Al-Iltiham } \\
\text { Al-taaliq }\end{array}$ \\
\hline 7 & Faleh Al-Ajmi & 1999 & Al-tamasok & Al-tanaseq \\
\hline 8 & Ahmed Afifi & $\begin{array}{l}2001 \\
2005\end{array}$ & $\begin{array}{l}\text { Al-sabek, Al-tamasok, Al- } \\
\text { rabet, Aletisaq, } \\
\text { Al-tadam, } \\
\text { Al-trabut Arrasfi }\end{array}$ & $\begin{array}{l}\text { Al-hubek, Al-tamasok, Al- } \\
\text { ensijam, } \\
\text { Al-trabut almfhumi }\end{array}$ \\
\hline 9 & Mahmoud Nehla & 2001 & Al-trabut & Al-tamasok \\
\hline 10 & Omar Abu Khurma & 2004 & Al-trabut, Aletisaq & Al-ensijam \\
\hline 11 & Naaman Bougherra & $\begin{array}{l}2007 \\
2009\end{array}$ & Al-rabet, Aletisaq & $\begin{array}{l}\text { Al-tamasok, } \\
\text { Al-ensijam }\end{array}$ \\
\hline & $\begin{array}{l}\text { Total Number of } \\
\text { Arabic terms }\end{array}$ & & 9 & 10 \\
\hline
\end{tabular}

According to Jamaan Abdul Karim, (2007, p. 210), most text studies tend to "use (Al-tamasok) as an equivalent to (Cohesion) and the use of (Al-ensijam) as an equivalent for (Coherence)". Therefore, the researchers agree with Jamaan Abdul Karim, and support the adoption of these terms as described in the following points:

a) Researchers tend to use the term (Al-tamasok) to denote the standard (Cohesion) for the following reasons:

First, they rely on the linguistic connotation of the term (Al-tamasok); as it is based on a significant position in language dictionaries, the word (Al-tamasok) suggests that there are two or more parties, and that the correlation process between those parties is the so-called (Al-tamasok). Therefore, it can be said (Tamasok Al-Binaa, the cohesion of construction or Binaa Mutamasok, Cohesion Construction). If we look closely, we can find that this suggestive connotation is a unique property for the word (Al-tamasok) and not found in the other words such as (Al-sabek or Al-atisaq). Al-sabebk as stated in the linguistic root indicates the rigidity, strength retouch and melting, for example (metal melting). The term suggests these meanings more than elements cohesion. The word (Al-atisaq) in language dictionaries revolves around the completeness and moderation, for example: the term is used to describe the moon in its fullness. It also suggests meanings more than a mutual relationship or connection between two or more things.

Second: The terms of (Al-rabet and Al-tadam) are not appropriate to denote the term (Cohesion) because they are used a lot to refer to some means of text cohesion and its tools. (Al-rabet, Junction) as it is known; the most important means of grammatical cohesion. And (Al-tadam, collocation) is released by some scholars on a sequence of words or terms that co-occur more often than would be expected by chance. It is one of the means of lexical cohesion. So it is unacceptable to use one term for two different concepts. Sometimes the term (Al-rabet) is used to denote Cohesion and other times Junction.

Third: It is unacceptable to use (Al-tadam) sometimes for Cohesion, and sometimes for collocation, because that leads to a sort of confusion of terminology and the corresponding concepts. Therefore, the term $(A /-$ tamasok) is more general than (Al-rabet and Al-tadam) because they are of its tools, and their relation to (Altamasok) is part to whole.

Fourth: According to some researchers, the term (Al-etisaq), which is popularized in some studies, is not appropriate because of its proximity in the significance of linguistic indication to (Al-ensijam). The 
completeness and moderation are of the meanings of (Al-etisaq) in language dictionaries, but regularity and moderation are of the meanings of (Al-ensijam). The deep rapprochement between the semantic status of both terms leads to confusion and ambiguity. Thus, researchers are called to adopt the term (Al-tamasok) alone to indicate the standard Cohesion.

b) Adopting the term (Al-ensijam) to denote the standard Coherence for two reasons:

First: The term has become more common in recent studies than other terms, including the term of $(A /$ hubek) with its heritage roots.

Second: The term (Al-ensijam) has never been used to denote the standard Cohesion. Researchers use the term only to refer to the standard Coherence, contrary to what we have observed of mixing in the use of the term (Al-tamasok). So the study adopts the term (Al-tamasok) to denote the standard Cohesion and (Alensejam) can be the most appropriate term to denote the standard Coherence.

\section{CONCLUSION}

The disorder of the terms of Arabic text linguistics increases as scholars multiply its translations. The problem becomes more complex because of the multiplicity of terms that reflect one standard. This has led to the use of the same term for two standards. The result is conceptual confusion that escalates every day in several studies in this area, resulting in confusion and conflict and sometimes ambiguity in modern Arabic linguistic studies.

This study has monitored aside from the confusion, multiplicity and inconsistencies in the use of two terms of the most famous text linguistics and discourse analysis terminology: Cohesion and Coherence. The study proposes the adoption of two terms with a statement of justification for that choice.

\section{FINDINGS}

a. Perhaps the most important factor of term multiplicity exists in that some researchers vary their terminology with the diversity of their sources and research.

b. One of the reasons for the multiplicity of Arabic terms that reflect one standard is the multiplicity of the term by the western origin translator. For example, the term (Connection), a synonym for (Cohesion) in Western studies, has been translated by one Arab researcher as (Al-tarabut) while another translator has translated (Cohesion) to (Al-tamasok). This means that the disorder of using multiple terms to denote one standard is an extension of the disorder inherent in the Western translated studies.

c. Some researchers mixing between a term that expresses the standard, and terms that reflect its tools and mechanisms. For example, some researchers used the terms (Al-rabet and Al-tadam) to denote the standard (Cohesion), because they are used a lot to refer to text cohesion.

d. It is not suitable to use one term to different standards. For example, it is not acceptable to use (Al-rabet) once for (Cohesion), and another for (Junction).

e. It is not acceptable to use the term (Al-tadam) once for (collocation) and another for (Al-tamasok, Cohesion).

f. The main reason for this terminological disorder may be due to the movement away from the required rooting of the term; as many researchers have not paid attention to the eloquence and aesthetic function of the Arabic terms (Al-sabek and Al-hubek) which are commonly used on a large scale by old writers and critics. (Al-sabek) suggests very cohesion, hardly be separated, while (Al-hubek) means only tension. This rooting in such situations would help to avoid a lot of confusion and overlap.

g. The application of many Arabic terms concerning Text Grammar theory on the Holly Qur'an would cause confusion to the reader regarding the concepts of the results of those applications. Therefore it is necessary to work on the standardization of terminology of such standards.

\section{RECOMMENDATIONS}

a. The need to standardize text linguistics terminology and discourse analysis.

b. Adoption of the term (Al-tamasok) to denote the standard (Cohesion) and the term (Al-ensijam) to denote the standard (Coherence) for reasons clarified by the study.

c. Inviting senior researchers, translation experts and specialists of Arabic linguistic studies to develop a standardized glossary of terms of Text Linguistics and Discourse analysis to adopt a specific term for each standard. 


\section{ACKNOWLEDGEMENT}

This paper is a part of the research entitled "Applications of Text Grammar Theory on the Qur'an: A Critical Study on Selected Thesis and Articles". Funded by: Research Management Centre at Universiti Sains Islam Malaysia (USIM), Grant No. PPP/ USG-0115/FPBU/ 30/11515. Therefore, the researchers appreciate the great support of the PPP.

\section{REFERENCE LIST}

De Beaugrande, R. (1980). Text Discourse and Process, Alex Publishing Corporation, Norwood, New Jersey: USA.

De Beaugrande, R. \& Dressler, W. (1981). Introduction to Text Linguistics. Longman, London: UK \& New York: USA.

Halliday, M.A.K. \& Hasan, R. (1976). Cohesion in English. Longman. London: UK \& New York: USA.

Van Dijk, T. A. (1972). Some Aspects of Text Grammar, Hague: Mouton: Netherlands.

Van Dijk, T.A. (1977). Text and Context: Explorations in the Semantics and Pragmatics of Discourse. Longman: London, UK.

\section{References in Arabic Language}

$$
\text { بحيري، سعيد. (1997). علم لغة النص الدفاهيم والاتجاهات . ط1. القاهرة: الثركة المصرية للنشر. }
$$

أبو غزالة، إلهام. وخليل، على. (1992). مدخل على إلى علم لغة النصّ. نرجمة ونطبيقات لنظرية روبرت دي بوجراند ولفجانج دريسلر.

$$
\text { ط1. نابلس. فلسطين: مطبعة دار الكاتب. }
$$

بوقرة، نعمان. (2007). نحو النص؛ مبادئه واتجاهاته الأساسية في ضوء النظرية اللسانية الحديثة. علامات في النقد. جدة. 61

بوقرة، نعمان. (2009). المصطلحات الأساسية في لسانيات النص وتحليل الخطاب. ط1. عمان. الأردن: عالم الكتب الحديث. حسان، تمام. (2007). اجتهادات لغوية. ط1. القاهرة: عالم الكتب.

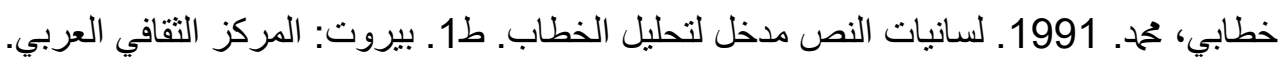

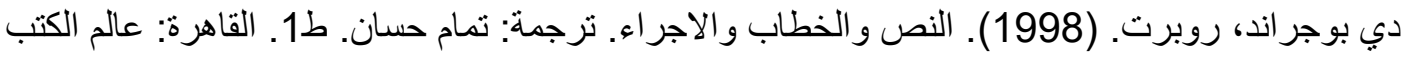
شبل، عزة. (2009). علم لغة النص النظرية و التطبيق. ط2. القاهرة: مكتبة الآداب.

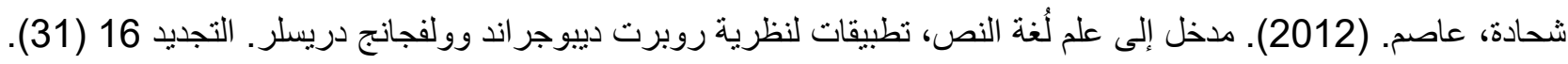

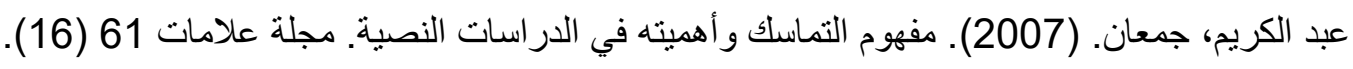
عفيفي، أحمد. (2001). نحو النص اتجاه جديد في الدرس النحوي. ط1. القاهرة: مكتبة زهر اء الثباء الثرق.

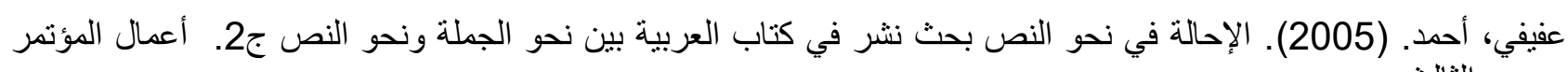
الثالث

$$
\text { للعربية والدراسات النحوية 22-23 فبر اير كلية دار العلوم القاهرة. }
$$

فضل، صلاح. (1992). (1992). بلاغة الخطاب و علم النص. سلسلة عالم المعرفة. الكويت: المجلس الوطني للثقافة والفنون والآداب

مصلوح، سعد. (1991). نحو أجرومية للنص الشعري. دراسة في قصيدة جاهلية. مجلة فصول. 10 (1 و 2). نحلة، محمود أحمد. (2001). علم اللغة النظامي مدخل إلى النظرية اللغوية عند هاليداي ط2. ملتقى الفكر. 